\title{
ASSERTIVENESS TRAINING CAN INCREASE NURSING STUDENT CONFIDENCE
}

\author{
(Assertiveness Training Meningkatkan Kepercayaan Diri Mahasiswa)
}

\author{
Dayat Trihadi $^{*}$, Etlidawati Silvi*, Dwi Kania Murtiasih ** \\ * Faculty of Health Science Muhammadiyah University of Purwokerto \\ Kampus II : Jl. Letjend Soeparjo Roestam Km. 7 Po Box 229 Purwokerto 53181 \\ ** General Hospital City of Banjar, Banjar, West Java, Indonesia \\ E-mail: dayatrihadi@gmail.com
}

\begin{abstract}
ABSTRAK
Pendahuluan: Mahasiswa memiliki kepercayaan diri untuk menghadapi tantangan ini. Salah satu upaya untuk meningkatkan kepercayaan diri adalah dengan Assertiveness Training. Terapi ini dilakukan dalam lima sesi dengan metode menggambarkan, pemodelan, bermain peran, umpan balik, dan mentransfer. Penelitian ini bertujuan untuk mengetahui pengaruh Assertiveness Training dalam meningkatkan kepercayaan diri mahasiswa Ilmu Kesehatan di Universitas Muhammadiyah Purwokerto. Metode: Penelitian ini menggunakan metode kuasi eksperimen dengan desain pretest-posttest dengan kelompok kontrol dengan uji statistik yaitu Dependent dan uji Sampel Independent T tes. Teknik pengambilan sampel menggunakan Cluster Random Sampling. Sampel dalam penelitian ini adalah 41 mahasiswa dari S-1 keperawatan sebagai kelompok intervensi dan 41 mahasiswa lainnya sebagai kelompok kontrol. Hasil : Hasil penelitian menunjukkan peningkatan percaya diri yang signifikan dari mahasiswa pada kelompok intervensi dan kelompok kontrol setelah kelompok intervensi diberikan pelatihan Assertiveness Training $(=0,000)$. Diskusi: Kesimpulan dari penelitian ini adalah latihan asertif dapat meningkatkan rasa percaya diri mahasiswa. Hasil penelitian ini dapat menjadi masukan bagi tenaga kesehatan, khususnya perawat untuk meningkatkan kemampuan untuk memberikan tindakan keperawatan, sebagai konselor, dan sebagai seorang pendidik.
\end{abstract}

Kata Kunci: Assertiveness training, Mahasiswa, Percaya diri

\begin{abstract}
Introduction: Students to have the confidence to face these challenges. One of the efforts to boost confidence is with assertiveness training. This therapy is done in five sessions with the method of describing, modeling, role play, feedback, and transferring. This study aims to determine the influence of assertiveness training in increasing Nursing student confidence of Nursing Health Science in the Muhammadiyah University of Purwokerto. Methods : This study uses quasiexperiments method with a pretest-posttest design with a control group with statistical tests namely Dependent (Paired) and tests Independent Samples T test. Sampling technique uses Cluster Random Sampling. Samples in this study were 41 students of S-1 nursing as the intervention group and the other 41 students as a control group. Results : The results of the study showed a significant different increase statistically confidence of the students in the intervention group and control group after the intervention group is given assertiveness training $(\rho v=0,000)$. Discussion: The conclusion of this research is assertiveness training can increase students confidence. The results of the study can be input for health workers, especially nurses to improve the ability to provide nursing actions, as a counselor, and as an educator.
\end{abstract}

Keywords: Assertiveness Training, Students, Self Confidence

\section{INTRODUCTION}

Students are young people between the ages of 19-28 years who are in the age of experiencing a transition from juvenile to adult stage (Siregar, 2006, p. 20). According to Kenniston (in Siregar, 2006, p. 20) says that the student is a period called the studenthood (apprenticeship), which occurs only in individuals who enter post secondary and before entering into the world of work is settled. According to Law No. 20, 2003 on
National Education System Chapter VI section four of article 19, the student is a high student or someone who studied at universities or university (Warti 2011, p. 1). Students not only the students who take the classes, then go home and study for midterm exams and semester exams, but students are required to have good soft skills because someday the students will live in the midst of diverse community.

Students are members of the public that have certain characteristics, which have 
the ability and the opportunity to study at university, so it can be classified as the intelligence, can act as a leader capable and skilled, both as leader of the community or in the workplace, may be a power driving dynamic to the process of modernization, can enter the world of work as a qualified workforce and professional (Kartono 1985 in Siregar, 2006, p. 5). In carrying out that role, in addition to intelligence also necessary confidence in each student.

Future students is a period full of challenges and difficulties, a time that requires students determine the attitudes and options (Kartono 1986 in Siregar, 2006, p. 4). Thus the required confidence to overcome these challenges. Indrayanto research results (2010) about the problems faced by teenagers obtained the data that $9.9 \%$ of teenagers is cheating. Indika research results (2010) obtained data is that $28 \%$ of teenagers are not confident because of obesity.

Students who do not have selfconfidence actually wanted to express what you want to be delivered, but do not know how to communicate well, the type of student who was classified as passive students. In everyday life both in the academic environment and in society assertiveness is recommended. Therefore, researchers will test the assertiveness training to increase the confidence of students.

Nursing students at FIKES UMP have not discount high confidence. During the exam, there is still much to cheating, embarrassed to ask questions when in class, abusing tuition for other purposes. Falsifying signatures when the practice in the hospital, fighting with hospital nurses, SMS language disrespectful to the supervisor when the industry practice. When the discussion did not want an expression for fear of being wrong, confused initiate a conversation if you meet a new friend. This suggests that self-confidence is very important.

According to Judge 2005 (in Rohayati 2011, p. 370), confident every person is one soul power that determines the success or failure in achieving the goal of his life. Confidence is something that is priceless. With a look of confidence, one can do anything with the confidence that it will work, if it has failed, a person does not necessarily desperate, but still have the spirit, remains to be realistic, and then steadily tried again (Widarso 2005 in Rohayati 2011, p. 370). Self-confidence is a major capital for success; strong self-confidence will lead to motivation and high morale.

Someone who does not have selfconfidence, the potential for self-owned inhibited. Signs and symptoms of someone who does not have the confidence of feeling low self-esteem, stupid, inadequate, inappropriate, difficulties in socializing difficult to get new friends, did not dare to start a conversation or introductions to other people, tense or nervous when facing the crowd, assume that others are great, shame express ideas or opinions, stage fright, fear of public speaking (public speaking phobia), focus on the weakness of self, often moody, easy to feel sad, and tired (Hypnotherapy Asia 2011).

Someone who does not have confidence will not be able to participate actively in the development of the nation. These conditions would be a thing that must be considered by the successors of the nation, especially the youth. Especially for young academics, in this case, the student. Students as a frontline nation building should be the courage to express his notions. Therefore, students must have a sense of confidence and should continue to be improved. Yet so far there are still many students who have or are still low self-confidence. It certainly can be a barrier of students in developing their potential.

Researchers conducted a preliminary survey by interviewing the students. Results obtained 8 out of 10 students said when speaking in public shy or nervous, confused to initiate a conversation, do not dare to ask questions, do not dare to put forward the idea, afraid of taking action and sometimes insecure. When viewed from the signs and symptoms of someone who does not have confidence in Hypnotherapy Asia 2011, some of the things said by a student of Nursing FIKES UMP belong to the signs and symptoms of someone who does not have self-confidence. Nursing Student FIKES UMP interviewed also said 
it wants to boost self-confidence. Based on these facts we need the training to improve the self-esteem of students, such training can be either positive affirmations, hypnotherapy, counseling peers, and assertiveness training.

From the description of confident students can be formulated research problem is "How does assertiveness training for nursing students increase confidence FIKES UMP 2016".

The general objective of this research was to determine the effect of assertiveness training for nursing students increase confidence FIKES UMP Year 2016. While the specific objective, namely Identify the level of confidence of students before and after given assertiveness training and identify the effect of assertiveness training for nursing students increase confidence. The usefulness of this research to Provide an overview of the characteristics of students who lack confidence, know the effect of assertiveness training to increase self-confidence, results of this study can give a superficial form of therapy to improve confidence in the nursing students

\section{METHOD}

This study uses a quasi experimental using pre-post test design with control group design. Experimental quasi Design is a design study has a control group and have requirements - requirements as experimental research is not adequate (Notoatmodjo 2010, p 56). Pre-posttest control group design is the design of the grouping members - members of the control group and the experimental group by random or random. Then do the pretest (01) in the group, and followed by the intervention $(\mathrm{X})$ in the experimental group. After some time do posttest (02) in the group (Notoatmodjo 2010, p. 58).

So in this study, the sample was divided into two groups: Assertive Training is given and the group that was not given Assertive Training. The research instrument was a tool or facility used by researchers to collect data so that job easier and the results better (accurate, complete and systematic) so it is more easily processed (Saryono 2008, p. 85). Instruments used in this study is collecting data using questionnaires. These instruments are classified as follows: Instruments A contains biographical data of respondents and instruments B which is an instrument for measuring the confidence of students consists of 37 statements containing the statement, used to determine the confidence of students. The questionnaire was given students who want to become respondents. Data entry sheet statement made by the researcher. Data were collected on all students and be willing to follow Assertive Training. The assertive Training process is conducted on a group of nursing students. In the sampling, the researchers used the sampling technique is purposive sampling and also coinciding with the inclusion criteria, the sample obtained 41 respondents to the intervention group and 41 respondents to the control group, so it adds up to 82 respondents. After respondent had determined, the researchers began to contract time by all respondents. Then the researchers calculated the average number of students using a questionnaire confident. The results are to believe the data on the pretest research. Then, having taken their data and student respondents intervention group was given Assertive Training. Assertive Training was given to students consist of 5 sessions.

\section{Results and Discussion}

This research was conducted in FIKES UMP with research time began on April 17 to May 24, 2016. Data were obtained from questionnaires filled out by the respondents. Implementation of assertiveness training began on May 8, 2016, by way of in-class training. Before the respondents follow assertiveness training, one week prior to a contract researcher for the time of filling the questionnaire and the implementation of assertiveness training. One day before the implementing respondents to fill out questionnaires. Implementation research began on 17 April 2016 for the survey schedule of lectures and student activities that will be the respondent. Researchers get the respondent on 23, April 27 and May 7, 2016. The implementation of assertiveness training, 
followed by 41 respondents. All respondents follow the sessions in the implementation of assertiveness training consisting of 5 sessions. Posttes to measure confidence took place on 23 and May 25, 2016.

Table 1 shows that the average age of the respondents in the intervention group 20.19 years old, with a standard deviation of 1.327. Age lowest 18th and 22nd highest. In the control group the average age of the respondents to 20.46 years old, with a standard deviation of 1.266. Age 18th lowest and 22 the highest.

Table 2 shows that most of the intervention group sex male (53.7\%). While in the control group was mostly male sex (51.2\%). Confident students were analyzed using univariate and bivariate analysis. The univariate analysis presented in a tabular form the distribution of average scores to determine the confidence of students before and after implementation of assertiveness training. While the bivariate analysis was conducted to determine the difference confident students.
In bivariate analysis, analysis of test used is a parametric analysis using $t$ tests Dependent and Independent $t$ Test. Dependent $t$ test is used for the same sample, and Independent $t$ Test is used for different samples.

Based on Table 3, shows the average scores of confidence before the intervention group was given assertiveness training were 97.3 medians 99 with a standard deviation of 8.07, and the highest 77 lowest scores 111 .

Table 4 shows the average scores of confidence after the intervention group was given assertiveness training is the 112.24 median 114 with a standard deviation of 8.14, and the highest 93 lowest scores 120 .

Table 5 shows the average scores of confidence the control group before the intervention group was given assertiveness training was 97.24 with a standard deviation median 998 Highest Lowest score 74 and 109.

Table 6 shows the average scores of confidence the control group after the

Table 1. Characteristics of Respondents by Age Respondents in the intervention group and the control group in FIKES UMP 2016

\begin{tabular}{lllccc}
\hline \multicolumn{1}{c}{ Group } & N & Mean & SD & Min & Maks \\
\hline Interv & 41 & 20,19 & 1,327 & 18,00 & 22,00 \\
Kont & 41 & 20,46 & 1,266 & 18,00 & 22,00 \\
\hline
\end{tabular}

(Sumber: Data Primer 2016)

Table 2. Characteristics Respondents by Gender the intervention group and the control group in FIKES UMP 2016

\begin{tabular}{crcccc}
\hline \multirow{2}{*}{ No } & \multirow{3}{*}{ Gender } & \multicolumn{4}{c}{ Kelompok } \\
\cline { 3 - 6 } & & \multicolumn{2}{c}{ Intervensi } & \multicolumn{3}{c}{ Kontrol } \\
\cline { 2 - 6 } & & Freq & \% & Freq & \% \\
\hline 1 & Male & 22 & $53,7 \%$ & 21 & $51,2 \%$ \\
2 & Female & 19 & $46,3 \%$ & 20 & $48,8 \%$ \\
Total & & 41 & $100 \%$ & 41 & $100 \%$ \\
\hline
\end{tabular}

(Sumber: Data Primer 2016)

Table 3. Average Score Confidence S-1 Nursing Students in Group Intervention Before Awarded Assertiveness Training in FIKES UMP 2016

\begin{tabular}{llllllll}
\hline Group & & N & Mean & Median & Sd & Min & Max \\
\hline Intr & 41 & & 97,3 & 99 & 8,07 & 77 & 111 \\
\hline
\end{tabular}

(Sumber: Data Primer 2016) 
Table 4. Average Score Confidence S-1 Nursing Students in Group Intervention After Assertiveness Training Provided in FIKES UMP 2016

\begin{tabular}{ccccccc}
\hline \multicolumn{1}{c}{ Group } & N & Mean & Median & Sd & Min & Max \\
\hline Intrvns & 41 & 112,24 & 114 & 8,14 & 93 & 120 \\
\hline
\end{tabular}

(Sumber: Data Primer 2016)

Table 5. Average Score Confidence S-1 Nursing Students on Intervention Group Control Group Before Assertiveness Training Provided in FIKES UMP 2016

\begin{tabular}{ccccccc}
\hline Group & N & Mean & Median & Sd & Min & Max \\
\hline Kontrol & 41 & 97,24 & 99 & 8 & 74 & 109 \\
\hline
\end{tabular}

(Sumber: Data Primer 2016)

Table 6. Average Score Confidence, S-1 Nursing Students in Control Group Intervention Group, Awarded After Assertiveness Training in FIKES UMP 2016

\begin{tabular}{ccccccc}
\hline Kelmpk & N & Mean & Median & Sd & Min & Max \\
\hline Kontrol & 41 & 97,19 & 99 & 8,04 & 74 & 109 \\
\hline
\end{tabular}

(Sumber: Data Primer 2016)

Table 7. Difference Analysis Average Score Confident student on Before and After the Intervention Group Awarded FIKES UMP Assertiveness Training in 2016.

\begin{tabular}{llccccc}
\hline \multicolumn{1}{c}{ Confident } & N & Mean & Sd & SE & t & pv \\
\hline Pre tes & 41 & 97,34 & 8,07 & 1,26 & & \\
Post tes & 41 & 112,2 & 8,14 & 1,27 & & \\
(Pre tes-Post tes) & 41 & 14,90 & 10,64 & 1,66 & 8,96 & 0,000 \\
\hline
\end{tabular}

(Sumber: Data Primer 2016)

intervention group was given assertiveness training is median 9997.19 with a standard deviation of 8.04, and the highest 74 lowest scores 109.

To know the difference confident students after the intervention group was given assertiveness training using test Dependent Samples T Test. The results of the analysis of the complete data are listed in the table below :

Table 7 shows the Dependent test Samples T Test generates value pv $=0.000$. Values statistically illustrate that there are differences in the average scores of confidence of students in the intervention group before and after being given assertiveness training $(\mathrm{pv}=0.000<\alpha=0.05)$.

As for the $t$ test calculation, there is a result that $t$ is 8.96 . The results of the $t$ compared with $t$ table, where the table $t$ the use of degrees of freedom $(\mathrm{df}=\mathrm{db}=\mathrm{df})=\mathrm{n}-1$
$=41-1=40 \mathrm{~T}$ table obtained was 2,021, while the $t$ acquired is 8.96 , From this comparison it can be seen that $t$ is greater than $t$ table, which means statistically is Ho refused or $\mathrm{Ha}$ accepted. Means there is an average difference was statistically confident students before and after being given assertiveness training.

According to Townsend (2007, p. 11), assertiveness training is a training program to train a person's behavior conveying the needs, rights, and make choices without ignoring the rights of others. The end goal would be expected in assertiveness training is to establish the assertive behavior that is able to communicate with others or interact, with both capable of expression, interpersonal communication skills training properly so as to increase confidence.

According to Stuart and Laraia 2005 (in Wahyuningsih 2009), which included the ability of assertive behavior, namely 
Table 8. Difference Analysis Average Confidence Students In Control Group Before and After Intervention Group Awarded FIKES UMP Assertiveness Training in 2016.

\begin{tabular}{lcccccc}
\hline \multicolumn{1}{c}{ Percaya Diri } & N & Mean & Sd & SE & t hitung & $\boldsymbol{p v}$ \\
\hline Pre tes & 41 & 97,24 & 8 & 1,24 & & \\
Post tes & 41 & 97,19 & 8,04 & 1,25 & 1,000 & 0,323 \\
Pre tes-post tes & 41 & 0,04 & 0,31 & 0,48 & & \\
\hline
\end{tabular}

(Sumber: Data Primer 2016)

Communicate directly with another person, say 'no' to requests that are not rational, have the ability to express disapproval, and express appreciation appropriately. To gain the ability of assertive behavior principles in assertiveness training.

The principle is considered in Assertiveness training is skills training and communication techniques used. Skills are trained in assertiveness training is to train individuals to understand assertive and passive behavior, identifying personal rights and others, improve assertive skill through the practice directly. While communication technique to be considered in the implementation of assertiveness training, namely: using assertive body language, use the statement 'I', this statement focuses on problems instead of blaming others.

Assertive body language that needs to be trained in the implementation of assertiveness training is appropriate eye contact, facial expressions in accordance with talks, upright and relaxed posture, nonverbal communication skills and choice of words need to be considered (Wahyuningsih, 2009).

At assertiveness training consists of five sessions: session one know themselves, identify problems two sessions, three sessions to train express their thoughts and feelings, four training sessions to understand the confidence, and five training sessions boost confidence. In each session, there is a written assignment.

To know the difference confident student control groups before and after the intervention group was given assertiveness training using test Dependent Samples T Test. More analysis results are listed in the table below.
Table 8 shows the Dependent test Samples T Test generates value pv $=0.000$. Values statistically illustrate that there are differences in the average scores of confidence of students in the intervention group before and after being given assertiveness training $(\mathrm{pv}=0.000<\alpha=0.05)$.

As for the $t$ test calculation, there is a result that $t$ is 8.96 . The results of the $t$ compared with $t$ table, where the table $t$ the use of degrees of freedom $(\mathrm{df}=\mathrm{db}=\mathrm{df})=\mathrm{n}-1$ $=41-1=40 \mathrm{~T}$ table obtained was 2,021, while the $t$ acquired is 8.96 , From this comparison it can be seen that $t$ is greater than $t$ table, which means statistically is Ho refused or Ha accepted. Means there is an average difference was statistically confident students before and after being given assertiveness training.

According to Townsend (2007, p. 11), assertiveness training is a training program to train a person's behavior in conveying the needs, rights, and make choices without ignoring the rights of others. The end goal would be expected in assertiveness training is to establish the assertive behavior that is able to communicate with others or interact, with both capable of expression, interpersonal communication skills training properly so as to increase confidence.

According to Stuart and Laraia 2005 (in Wahyuningsih 2009), which included the ability of assertive behavior, namely Communicate directly with another person, say 'no' to requests that are not rational, have the ability to express disapproval, and express appreciation appropriately. To gain the ability principles of assertive behavior in assertiveness training.

The principle is considered in Assertiveness training is skills training and 
Table 9. Difference Analysis Average Confidence Students In Control Group Before and After Intervention Group Awarded FIKES UMP Assertiveness Training in 2016

\begin{tabular}{lccccc}
\hline \multicolumn{1}{c}{ Kelompok } & N & Mean & SE & t hitung & $\boldsymbol{p v}$ \\
\hline Intervensi & 41 & 112,24 & 1,27 & & \\
Kontrol & 41 & 97,19 & 1,25 & 8,419 & 0,000 \\
\hline
\end{tabular}

communication techniques used. Skills are trained in assertiveness training is to train individuals in understanding assertive and passive behavior, identifying personal rights and others, improve assertive skill through the practice directly. While technique communication to be considered in the implementation of assertiveness training, namely: using assertive body language, use the statement 'I', this statement focuses on problems instead of blaming others.

Assertive body language that needs to be trained in the implementation of assertiveness training is appropriate eye contact, facial expressions in accordance with talks, upright and relaxed posture, nonverbal communication skills and choice of words need to be considered (Wahyuningsih 2009).

At assertiveness training consists of five sessions: session one know themselves, identify problems two sessions, three sessions to train express their thoughts and feelings, four training sessions to understand the confidence, and five training sessions boost confidence. In each session, there is a written assignment.

To know the difference confident student control groups before and after the intervention group was given assertiveness training using test Dependent Samples T Test. More analysis results are listed in the table below.

Table 9 shows the test Independent Samples T Test generate value pv $=0.000$. Values statistically illustrate that there are differences in the average scores of confidence of students in the intervention group and the control group before and after being given assertiveness training ( $\mathrm{pv}=0.000<\alpha=0.05$ ).

As for the $t$ test calculation, there is a result that $t$ is 8.41 . The results of the $t$ compared with $t$ table, where the table $t$ the use of degrees of freedom $(\mathrm{df}=\mathrm{db}=\mathrm{df})=\mathrm{n}-1$ $=41-1=40 \mathrm{~T}$ table obtained was 2.02 while the $t$ acquired is 8 , 41. From this comparison it can be seen that $t$ is greater than $t$ table, which means statistically is Ho refused or $\mathrm{Ha}$ accepted. Means that there are differences in average statistically confident students in the intervention group and the control group before and after being given assertiveness training.

Increased trust in the intervention group confirms Stuart and Laraia 2005 (Wahyuningsih 2009) that assertiveness training is one way to boost confidence.

According to Waterman, 1988 (in Indrayanto 2010, p. 85) characteristic of someone who has the confidence will tend to be optimistic. This is supported by a statement Fatimah 2006 (Kusumawardani 2011). characteristics of individuals who have the confidence that is proportional, among which:

a. Believe in the ability of self, so it does not need praise, recognition, acceptance, or respect from others.

b. Not compelled to show the attitude for the sake confirms accepted by another person or group

c. Dare to accept and deal with resistance (not Moodi and emotionally stable)

d. Have an internal locus of control (see the success or failure, depending on their own business and not easily surrender to fate or circumstances and does not depend on the help of others).

e. Having realistic expectations, so that when hope is not realized is able to see the positive side of himself and the situation

Added by Guilford in 1959, Lauster 1978, Instone, 1983 (in Kusumawardani 2011, p. 22), the characteristics of individuals who have self-confidence is as follows: 
a. Individuals feel adequate for their actions. This is based on their conviction in the strength, abilities, and skills that I owned.

b. Individuals feel accepted by the group

c. Individuals believe in him and have a peace gesture

From both the above opinion, it can be concluded that characteristics of individuals who have self-confidence are:

a. Individuals feel accepted by the group

b. Individuals believe in him and have a peace gesture

c. Not compelled to show the attitude for the sake confirms accepted by another person or group

d. Dare to accept and face rejection

e. Self-control was good (not moody and emotionally stable)

f. Have an internal locus control

g. Have a sense of a positive view of self, others, and the situation outside him

h. Having realistic expectations

With a look of confidence, one can do anything with the confidence that it will work, if it has failed, one does not necessarily desperate, but still, have the spirit, remains to be realistic, and then steadily tried again (Widarso 2005 in Rohayati 2011, p. 3). Selfconfidence is a major capital for success; strong self-confidence will lead to motivation and high morale. (PDPI 2011; Notoatmodjo 2003)

\section{REFERENCE}

Ali, M dan Asrori, M 2008, Psikologi remaja: Perkembangan peserta didik, Bumi Aksara, Jakarta.

Anggraeni, Meika Fitri 2010, Pengaruh senam reumatik terhadap penurunan nyeri pada penderita osteoarthritis di kecamatan Cilacap Tengah 2010, Skripsi, tidak dipublikasikan, Prodi S-1 Keperawatan, Cilacap.

Aprilia, Yesie 2011, Cara menggunakan afirmasi dan visualisasi, dilihat 27 Desember 2011, <http://www. bidankita.com/index.php?option=com content\&view =article\&id=279:caramenggunakan-affirmasi-avisualisasi\&catid=40:monthlyguide\&Itemid $=34>$.

Arikunto, Suharsimi 2010, Prosedur penelitian, Rineka Cipta, Jakarta.

Cara Melaporkan Hasil Analisis Statistik 2011, dilihat 11 Januari 2012, <http://staff. ui.ac.id/internal/140102741/material/ Generalisasisampelkepopulasi.pdf $>$.

Chamidah, Atin Nur 2007, Deteksi dini gangguan pertumbuhan dan perkembangan anak, dilihat 1 Januari 2012, <http://journal.uny.ac.id/index. php/jpk/article/view/102/37>.

Gunarya, Arlina 2011, Membangun percaya diri, dilihat 20 Desember 2011, < http:// repository.unhas.ac.id/bitstream/ handle/123456789/29/3\%20MD03-\%20 Hand-Out $\% 20$ Percaya $\% 20$ Diri. pdf?sequence $=1>$

Grace 2011, Tes percaya diri, dilihat 22 Desember 2011, <http://shape-indonesia. $\mathrm{com} / \mathrm{q}=$ node $/ 61>$.

Hypnoterapi Asia 2011, Percaya Diri, dilihat 22 Desember 2011, <http://www. hipnoterapi.asia/percaya_diri.htm $>$.

Indika, Kinanti 2010, Gambaran citra tubuh pada remaja yang obesitas, dilihat 19 Desember 2012, <http://repository.usu. ac.id/bitstream/123456789/7334/1/060 09830(1).pdf $>$.

Indrayanto, Bayu Widya 2010, Pengaruh pelatihan kepercayaan diri menggunakan metode hipnosis terhadap kepercayaan diri siswa kelas $x$ dalam menghadapi ujian semester, dilihat 22 Desember 2011, <http://etd.eprints.ums. ac.id/8108/1/F100050262.pdf $>$.

Kusumawardani, Annisa 2011, Pengaruh terapi afirmasi positif terhadap kepercayaan diri remaja di SMA kotatip Cilacap, Proposal Metopen, Prodi S1 Keperawatan, Cilacap.

Macfoedz, Ircham 2009, Metodologi penelitian, Fitramaya, Yogyakarta.

Mulyono, Ninin Kholida 2007, Proses pencarian identitas diri pada remaja muallaf, dilihat 4 Januari 2012, $<$ http://eprints.undip.ac.id/10124/1/ Skripsi_Ninin_Kholida_Mulyono (M2A_002_059).pdf>. 
Murti, Bhisma 2010, Desain dan ukuran sampel untuk penelitian kuantitatif dan kualitatif di bidang kesehatan, Gadjah Mada University press, Yogyakarta.

Notoatmodjo, Soekijo 2002, Metodologi penelitian kesehatan, Rineka Cipta, Jakarta. 2005, Metodologi Penelitian kesehatan, Rineka Cipta, Jakarta. 2010, Metodologi penelitian kesehatan, Rineka Cipta, Jakarta.

Pamungkas 1972, Pedoman umum ejaan yang disempurnakan, Giri Surya, Surabaya.

Pedoman Kesehatan Remaja 2011, Pedoman kesehatan remaja, dilihat 9 Januari 2012, <http://dinkes-sulsel.go.id/new/ images/pdf/pedoman/pedoman $\% 20$ kes\%20jiwa\%20remaja.pdf $>$.

Pengertian Kepercayaan Diri 2011, Pengertian kepercayaan diri, dilihat 21 Februari 2012, <http://belajarpsikologi. com/pengertian-kepercaya $n$ diri/\#ixzz1hiHOgt5G>.

Prasetya, Hanung 2011, Modul pelatihan one day smart hypnotherapy for nursing, Holistic Nursing Care, Solo.

Populasi dan penarikan sample 2011, Populasi dan penarikan sample, dilihat 27 Januari 2012, <http://www.google. co.id/url?sa $=$ t\&rct $=\mathrm{j} \& \mathrm{q}=$ syarat $\% 20$ m enggun a kan \% 20 t ot a $1 \% 20$ sampling\& source $=$ web $\& c d=8 \& v e$ $\mathrm{d}=0 \mathrm{CFAQFjAH} \& \mathrm{url}=\mathrm{http} \% 3 \mathrm{~A} \% 2 \mathrm{~F}$ $\% 2$ Fakungenerations.files.wordpress. com\%2F2011\%2F02\%2Fpenarikansample.pptx\&ei=n94hT8qIIcTSrQf_6v H2Bw\&usg=AFQjCNFy3lgJ1D_8UkT PiMkpNmRWxyG52A\&cad=rja $>$.

Retnowati, Sofia 2011, Remaja dan permasalahannya, dilihat 1 Januari 2012, >.

Riyanto, Agus 2009, Aplikasi metodologi penelitian kesehatan, Muha Medika, Yogyakarta.

2011, Aplikasi metodologi penelitian kesehatan, Muha Medika, Yogyakarta.

Rohayati, Iceu 2011, Program bimbingan teman sebaya untuk meningkatkan percaya diri, dilihat 20 Desember 2011, $<$ http://jurnal.upi.edu/file/36-ICEU ROHAYATI.pdf
Salbiah 2011, Konsep diri, dilihat 19 Desember 2011, <http://repository. usu.ac.id/bitstream/123456789/3599/1/ keperawatan-salbiah2.pdf $>$.

Metodologi Penelitian 2011, Metodologi penelitian, dilihat 27 Januari 2012, $<$ www.cs.ui.ac.id/WebKuliah/ MetodologiPenelitian/Sampling.ppt>.

Santrock, Jhon W 2003, Adolescence ( $\left.6^{\text {th }} \mathrm{ed}\right)$, Jakarta, Erlangga.

Saryono 2008, Metodologi penelitian kesehatan, Mitra Cendika, Yogyakarta

Sarwono, Jhonatan 2010, SPSS training, dilihat 27 Januari 2012, <http://www.google. co.id/url?sa $=$ t\&rct $=\mathrm{j} \& \mathrm{q}=$ pengertian $\% 20$ $\mathrm{t} \% 20$ test $\% 20$ dependen $\% 20$ dan $\% 20$ in dependen $\&$ source $=$ web $\& c d=1 \&$ ved $=$ 0CCcQFjAA\&url=http $\% 3 \mathrm{~A} \% 2 \mathrm{~F} \% 2 \mathrm{~F}$ www.jonathansarwono.info $\% 2$ Fteori spss $\% 2 F S P S S$ training.ppt\&ei=kuohT 8upDMrWrQfVuIybCA\&usg=AFQjC NE250f6AMOiay51ZrrjGmnSDTaV9 $\mathrm{w} \& \mathrm{cad}=\mathrm{rja}>$.

Siregar, Ade Rahmawati 2011, Motivasi berprestasi mahasiswa ditinjau dari pola asuh, dilihat 19 Desember 2012, $<$ http://repository.usu.ac.id/bitstream/1 23456789/7334/1/06009830(1).pdf >.

Sugiyono 2005, Metode penelitian kuantitatif kualitatif dan $R \& D$, Alfabeta, Bandung.

2011, Metode penelitian kuantitatif kualitatif dan $R \& D$, Alfabeta, Bandung.

Suhardita, Kadek 2011, Efektivitas penggunaan tekniik permainan dalam bimbingan kelompok untuk meningkatkan percaya diri siswa, dilihat 4 Januari 2011, <http:// repository.upi.edu/operator/upload/s kim_044178_chapter3.pdf $>$.

Sunardi 2011, Latihan asertif, dilihat 10 Januari 2012, <http://file.upi.edu/ Direktori/FIP/JUR._PEND._LUAR BIASA/196002011987031-SŪNARDI/ karya_tls-materi_ajar_pdf/LATIHAN_ ASERTIF.pdf $>$.

Sutisna, Ucu 2010, Bimbingan dan konseling, dilihat 20 Desember 2011, <http:// abstrak.digilib.upi.edu/Direktori/ T ES I S / B I M B I N G A N_DA N KONSELING/0807919_CUCU_ SUTISNA/T_BP_0807919_Chapter1. $\mathrm{pdf}>$. 
Syaifullah, Ach 2010, Tips bisa percaya diri, Gara ilmu, Jogjakarta.

Townend, Anna 2007, Assertiveness and diversity, Palgrave Macmillan, New York.

Wahyuningsih, Dyah 2009, Pengaruh asertif traning (at) terhadap perilaku kekerasan pada klien Skizoprenia di RSUD Banyumas, dilihat tanggal 7 September 2011, <http://eprints.lib.
ui.ac.id/3946/9/124678-TESIS0613\%20 D y a $\% 20 \mathrm{~N} 09 \mathrm{p}$ - P en g a r u h \% 20 Assertiveness-Kesimpulan.pdf $>$.

Warti, Ida 2011, Arti mahasiswa, dilihat 19 Desember 2011, <http://idhaa.student. umm.ac.id/download-as-pdf/umm blog_article_15.pdf $>$.

Zulkifli 2009, Psikologi perkembangan, PT Remaja Posdakayarya, Bandung. 